\title{
PROLOGUE: CLIMATE TRAUMA AND HURRICANE SANDY
}

Many of us have our own Hurricane Sandy, and I am no exception. So much depended on exactly where we were when the storm hit. While the Weather Channel on TV, before going dead for us in lower Manhattan, noted the hurricane's trajectory, little attention was given locally to the devastation in Cuba, Haiti, the Caribbean, Puerto Rico, and Canada. This was an international catastrophe, but as experienced by many, it was read as a thoroughly local event. ${ }^{1}$

Some people, like my students who lived in Brooklyn, hardly suffered at all, whereas others living near the New York City, Long Island, or New Jersey coasts had their homes wiped out. My experience was in between these extremes. But let me first caution that, as with all traumatic events, what an individual brings to the situation in terms of psychic strength or vulnerability makes all the difference. Suffering can't be quantified or even compared. There are so many different kinds of pain, so many different calibrations to do with class, race, wealth.

\section{MY EXPERIENCE}

Middle-class folks like us, living in apartment buildings without generators in lower Manhattan, got our share of the disaster. During that fateful night, the storm raged outside our fourteenth-floor apartment. The trees on the street below were bending or breaking, the rain very heavy, and the streets empty. But lights were on everywhere, and it didn't seem so bad. The next day I was mainly worrying about a trip to Pittsburgh I was supposed to take and about my work schedule.

But quickly that all changed. There was a sudden power outage. All media were out and with no phone service we had no information to go on. I looked out of the apartment window to see, for the first time ever, the 
shocking sight of an absolutely dark environment. The Empire State Building, the Con-Ed Building, the Zeckendorff apartment buildings, and other buildings usually lit up, were dark.

My personal vulnerability (a phobic tendency) in a catastrophe like this didn't help. I began to feel trapped in our apartment. We walked downstairs (first of several treks down and up the fourteen long, dark, narrow flights) to talk to the doormen and to get some coffee, food, and water. We finally learned that the outage so far was only below Thirty-Fourth Street and that those who could were moving to hotels or relatives uptown.

I will never forget that first morning, walking around what had been our familiar neighborhood, now utterly foreign with no electricity. I think everyone needs a lesson about our near total reliance on electricity. Seeing at last an open shop, although totally dark inside, we found some cans of Starbucks coffee and handed over our credit card. But it relies on electricity. In this unusual setting, people were freely sharing knowledge about what was open, where to find food, and so on. Someone said there was real coffee over in the West Village.

Going over there, we passed NYU's Bobst Library, and I was surprised to find it lit up. Once inside, I saw an image (one of several) that stayed powerfully with me: Bobst had opened its doors to the general public. The grand wide-open Bobst Library foyer was transformed into a crowded work space with double lines of computer terminals set up along the counters, thanks to NYU's generators. ${ }^{2}$ Because of the library access, email and the Internet became our way to reach the world uptown and beyond. Not only was communication opened up, but we could also use the toilets. Later, we realized we could even shower in NYU's gyms. When the library closed, we went back to the apartment, and dragged ourselves up the fourteen flights each carrying as big a bottle of drinking water as we could manage, along with cans of food. We found that if we walked about three flights, then took a rest, walked three more, rested again, and so on, we could manage it. I hated entering the dark apartment. Reading was difficult. So it was pretty much going to bed and trying to sleep.

By now most of the other people had left the building, which made me anxious about strangers getting in. Outside the apartment door, there was just a small glimmer from a single strobe light the doormen had left. Being without electricity made me suddenly aware that hall and stair lights had always been on before, day and night. It was scary to have darkness outside 
the apartment, and to look out on deserted streets from our windows. No lights, no people. Just dark buildings, like dead people with dead eyes. In the apartment I felt claustrophobic because of the flights of dark stairs that lay between me and the outside world. I hated being in the dark flat but also feared going down the stairs. And feared even more being on the empty streets.

I had a terrible scare on these stairs one day. Coming up on my own, I suddenly realized there was no-one else now going up or down, since most floors had no people on them, and that if something happened on the stairway, no-one would ever find me. I couldn't phone my husband as I would normally do. This brought on a panic attack and I couldn't climb any further. Luckily, as I was trying to calm myself, two women came out of one of the floors. I told them I was having an attack. They went back, got some water, calmed me down, and then walked with me up a flight or two until I felt better. After that, I made sure always to be with my husband on the stairs.

I couldn't sleep at night for fear of what might happen if there was a fire. Since there were so few people around, this was quite illogical. Still, I worried that there wouldn't be firemen to help, water to put out the fire, or doormen to call, given that, without electricity, they were unreachable. I lay in bed, blinds raised, waiting for the dawn to light up the building across the way. The flat was so dark that finally we decided to risk leaving a flashlight on so that, when I got up, there would be light.

Wandering the streets near Bobst on about the fourth day of the outage, we came upon what was to me a shocking sight. Outside the local Gristede's food store, where we normally shop, were mounds of huge plastic bags on the pavement. Management simply threw out the entire stock of what had been perfectly good food. I later found out that, after the frozen food was taken to a dumpster, people managed to open the lock and take home what they could carry. ${ }^{3}$

A big break for us came when some of our friends living on Fifty-Second Street got in touch and invited us up for a shower, dinner, and entertainment. We planned to go uptown every night from then on, eating out and catching a movie. Strangely, we were just on our way to do that, standing outside the apartment waiting for a taxi, when suddenly the lights went on. It was amazing. In a jiffy, our whole situation changed. The electricity was back. But was it really? I was not ready to rely on it and felt afraid to use 
the elevator until assured by the doormen that indeed the problem with the burnt out hub had been fully resolved.

\section{HURRICANE SANDY AS BORDER EVENT}

A bit like 9/11 (if on a different scale), Hurricane Sandy was a border event, a characteristic it shares with Hurricane Katrina. Both disasters had dramatic political, social and psychological impacts and marked a cultural change in the United States, an altered consciousness of Americans as citizens. In the case of Katrina, among other things, there was shame at the racism that emerged from beneath the perpetual cover-up. Governmental inefficiency or worse was also exposed. With Hurricane Sandy, in turn, came a heightened sense of class difference, awareness that the most economically vulnerable people were living in areas most exposed to storm damage. Age differences and mobility, linked to class, featured heavily in people's experiences, as evident in the media reporting. Each catastrophe offered a sense of things being irreversibly altered after the happening, of changed sensibilities, of changed feelings regarding security, safety, stability, and of being unable to rely on the environment.

There is no doubt that the two catastrophes highlighted America's class and race politics, since the people living in the areas most open to drastic flooding and storm damage were significantly minority or lower-class. As with Hurricane Katrina, Sandy provided an example of the environmental injustice analyzed by, for example, Ramachandra Guha and Rob Nixon. In that sense, both hurricanes revealed class disparities that are too often neatly hidden beneath pervasive normative codes (still in play after all this time) of the country as a "melting pot."

In comparison to other people, my husband and I were lucky. We did not lose our house and belongings as did so many, nor were we left abandoned in a flooded house as were others. The elderly were especially vulnerable to being left without recourse, as they were often unable to get up and move away as people were told to do. The scandal of NYU placing its research labs and patients' files on the basement floor of the Langone Medical Center, which was quickly flooded by the storm surge, will go down in history: It was either an incredible error or reflected the sense of climate stability, whereby no-one ever imagined a thirteen-foot storm surge could penetrate 
that far into lower Manhattan to flood that basement. The medical center's backup generator also failed or was flooded. The image of elderly and sick people being carried down many flights of stairs and transferred by taxi to other hospitals in the area is astounding. ${ }^{4}$ But also documented were the unprecedented efforts of doctors, nursing staff, police, and fire personnel in saving all the many patients who had to be moved and transferred. ${ }^{5}$

Sandy was a border event in exposing our complete reliance on electricity. It was a wake-up call in this as in other ways. As Michael Rubenstein remarks, writing about the meaning of electrification in Ireland for Irish literary modernity, 'once 'plugged in' to the electrical grid, the citizen is dependent and reconstructs daily life around a technology that exists only as a function of national infrastructure." ${ }^{\prime}$ As he correctly notes, in this reconstruction of everyday life, there "is a nearly instantaneous forgetting that accompanies it. [That is,] The transformation that occurs, while controversial and profoundly lived through at first, leaves everyday consciousness with astonishing rapidity." It was that "forgetting" about electricity in particular (but also plumbing and sanitation) that returned so dramatically, and traumatically, to consciousness when Hurricane Sandy hit. We were reminded brutally of what we had forgotten in that habituation and incorporation of public utilities into modern daily life that Rubenstein discusses. It was a supreme example of what Christopher Bollas (as Rubenstein reminds us) called "the unthought known that asserts its urgency in moments of crisis."

Hurricane Sandy was a border event in a final sense-of the division between scientists who link this extreme climate disaster to planet warming and those who deny such a relationship. Debates in the wake of Sandy revealed, then, a theoretical border. Arguments as to how far the extremity of this weather event was the result of global warming were all over the Internet. Amid the skepticism reported in Wikipedia's Hurricane Sandy site, there was nevertheless agreement that "One factor contributing to the storm's strength was abnormally warm sea surface temperatures offshore the East Coast of the United States-more than $3^{\circ} \mathrm{C}\left(5^{\circ} \mathrm{F}\right)$ above normal, to which global warming had contributed $0.6^{\circ} \mathrm{C}\left(1^{\circ} \mathrm{F}\right)$. As the temperature of the atmosphere increases, the capacity to hold water increases, leading to stronger storms and higher rainfall amounts." Some scientists saw the abnormally warm surface temperatures as part of some "natural variability," whereas others such as Harvard scientist Daniel Schrag believed Hurricane 
Sandy's thirteen-foot storm surge was an example of what will, by midcentury, be the "new norm on the Eastern seaboard."

The noted Stony Brook University oceanographer Malcolm Bowman was quoted widely in the wake of Hurricane Sandy (often in discussions with then New York City mayor Michael Bloomberg). Bowman argued that the city must erect extensive storm-surge barricades around its coast, on the model of those in The Netherlands and London..$^{10}$ Others disagreed but had few alternative suggestions. Responses to articles on the web include Jeff Tollefson citing "two studies published in February and March this year [2012] (which) suggest that warming due to increasing ice loss in the Arctic Ocean could be altering regional air circulation, causing a more meandering jet stream. ${ }^{\prime 1}$ The net effect, researchers say, is an increase in the likelihood of severe winter storms and other extreme weather events across the United States, Europe, and northern China. Although the idea remains controversial, some scientists wonder whether the same phenomenon could lead to an increase in hurricanes such as Sandy and Irene, which last year roared up the coast from North Carolina to New York and came perilously close to flooding the city as Sandy did. ${ }^{12}$

There is general agreement that Hurricane Sandy was a wake-up call not only to the United States but to coastal cities around the world. This is no doubt a global problem, with two powerful industrialized nations-China and the United States - at great risk that rising sea levels will endanger their harbors at the center of global shipping networks. As I go on to argue in this book, global collaboration on dangers facing world economies in the face of climate change is essential before it is too late. ${ }^{13}$ If wake-up calls cannot move governmental leaders, humanity's future is bleak. As Martin Hoffman has argued (in personal communication), humans may not be a suicidal species, as some have argued, so much as victims of a strong evolutionary drive to survive. In following our individual drive for securing the material necessities of life - a drive that soon becomes sheer greed-we may end up putting our species at risk. ${ }^{14}$

Indeed, we may have already begun the process by starting to destroy species and the very planet we need to sustain us. In reviewing Elizabeth Kolbert's book The Sixth Extinction, Al Gore notes Kolbert's highlighting "the role of man-made climate change in causing ... the current spasm of plant and animal loss that threatens to eliminate 20 to 50 percent of all living species on earth within this century." He went on to note that many find 
it "inconceivable that we could possibly be responsible for destroying the integrity of our planet's ecology. There are psychological barriers to even imagining that what we love so much could be lost—could be destroyed forever. As a result, many of us refuse to contemplate it. ${ }^{{ }^{15}}$

Such psychological barriers may be a reaction formation to the phenomenon of "Pretraumatic Stress Syndrome" (PreTSS) which I go on to theorize in this book. I situate pretrauma against the more familiar Post-Traumatic Stress Disorder (PTSD), which is a condition triggered in the present by past events. In pretrauma, on the other hand, people unconsciously suffer from an immobilizing anticipatory anxiety about the future. My experiences during Hurricane Sandy reflect the familiar PTSD — that is, I responded to the catastrophe through what it triggered about past traumas. However, having had this experience, I may now suffer from pretrauma-that is, living in fear of a future terrifying event of a similar kind.

Generalizing from my experience, I suggest cultures may now be entering a new era in which pretrauma is pervasive in the public sphere. In this new era, media of all kinds - journalism, the Internet, television, film, and literature-offer catastrophic futurist scenarios. In these scenarios, audiences are invited to identify with future selves in uncertain, dangerous, and ultimately unsustainable worlds. Such identifications result in a pretraumatized population, living with a sense of an uncertain future and an unreliable natural environment. My hope is that, instead of being passively terrified, audiences will begin to understand dystopian scenarios as warning humans of what they must, at all costs, avoid. 

CLIMATE TRAUMA 
